\title{
Import Inflows of Bangladesh: the Gravity Model Approach
}

\author{
Md. Mahmudul Alam (Corresponding author) \\ CRM, Marketing Division, Grameenphone Ltd. \\ 47 Shantinagar, Dhaka-1217, Bangladesh \\ Tel: 880-1711-503-782 E-mail: rony000@gmail.com \\ Md. Gazi Salah Uddin \\ School of Business, Presidency University \\ 11/A, Road-92, Gulshan-2, Dhaka 1212, Bangladesh
}

Tel: 880-1715-201-727 E-mail: salahuddin@presidency.edu.bd

Khan Md. Raziuddin Taufique

School of Business, Presidency University

11/A, Road-92, Gulshan-2, Dhaka 1212, Bangladesh

Tel: 880-1711-348-223 E-mail: raziuddint@presidency.edu.bd

\begin{abstract}
Bangladesh suffers from a chronic deficit in her trade balance. The paper is an attempt to explore the imports of Bangladesh which is one of the most significant factors responsible for unfavorable trade balance of the country. The aim of the study is to intend some initiatives for an attempt to ultimately reshaping the trade balance of Bangladesh with her foreign trade partners. The paper examines the existence of the gravity theory for the imports of Bangladesh with its eight major trading partner countries- India, China, Singapore, Japan, Hong Kong, South Korea, USA and Malaysia. The data set consists of yearly data from 1985 to 2003 in a panel approach. The paper comes across with the findings that the gravity theory is consistent with the imports of Bangladesh. That is, the geographical distance of Bangladesh with its partner countries has significant impacts on its imports. But in near future this may change because of different factors such as profitability, easy trade procedures, product delivery time etc. that influence the imports decision more than does the geographical distance. This paper finds mixed relationship between the GDP and imports of Bangladesh. It also shows that the imports of Bangladesh influence the domestic production very little because Bangladesh mostly imports consumer goods rather than capital goods. Moreover, the population of Bangladesh has significant impacts on imports which in turn implies that Bangladesh is not capable of producing adequate consumer goods to meet the increased demand resulted from high population growth. It also shows that partner countries' GDP has significant positive impacts and partner countries' population has mixed impact on imports of Bangladesh. This paper concludes that it will be an alarming situation for trade balance of Bangladesh if the imports continue to increase in such a pattern that the rate increases five to eight times more in respect of population increases and at the same time the ratio of capital goods in proportion of total imports decreases.
\end{abstract}

Keywords: Gravity Model, Imports, Gross Domestic Product (GDP), Population, Geographical Distance, Panel

\section{Introduction}

In the past, national economies were relatively self-contained entities, isolated from each other by barriers to cross-border trade and investment; by distance, time-zones, and language; and by national differences in government regulations, culture, and business systems. As these barriers are being minimized by taking different initiatives, the contribution of cross-border trade to the development of national economy is becoming significant. The economic development of Bangladesh is also, to a significant extent, affected by the trade flows with partner countries. Although Bangladesh suffers from a chronic deficit in her trade balance (Table-1), scope might be found to explore the most significant factor(s) 
responsible for unfavorable trade balance with a view to take some initiatives for an attempt to ultimately reshaping the trend of Bangladesh's trade balance with her foreign trade partners.

Import is one of the moist important factors responsible for trade balance. Due to trade deficit where import is higher than export, the imports of Bangladesh need to look from different dimensions. While analyzing on imports, the import trading partners also get focus. In addition, recently the imports of Bangladesh also have started to move from border country to other countries. Though Bangladesh shares three of her borders with India and none with China, China has emerged as the largest source of import for Bangladesh replacing India for the first time in 2006 (Table-2). The value of imported amount of Bangladesh was 13.75b taka from China and 12.41b taka from India in 2005-2006 fiscal, where in 2004-2005 it was $12.33 \mathrm{~b}$ taka from India and 6.94b taka from China.

The gravity model is a popular formulation describing the trade flows between different geographical entities. The theory says that there is negative relationship between geographical distance and trade volume which indicates that the lower distance influences for more trade and vice versa. As the imports of Bangladesh are geographically shifting, this paper aims at analyzing the gravity theory for Bangladesh. Moreover, this paper also finds out the impacts of home GDP, partner countries' GDP, home population, and partner countries' population on the imports of Bangladesh.

\section{Literature Review}

The empirical studies by Tinbergen (1962) and Linnemann (1966) showed trade flows follow the physical principles of gravity: two opposite forces determine the volume of bilateral trade between countries - the level of their economic activity and income, and the extent of impediments to trade. The latter includes, in particular, transportation costs, trade policies, uncertainty, cultural differences, geographical characteristics, limited overlap in consumer preference schemes, regulatory bottlenecks, etc. National borders are among these impediments, even for industrialized countries (Anderson and Van Wincoop, 2003).

Although trade potential primarily results from the matched export capacities and import demand (microeconomic), on a more aggregated level of analysis, proximity in demand, in per capita income, in space, and in culture, are the potential macroeconomic determinants of export. Thus various combinations of macroeconomic variables, such as gross domestic product (GDP) and population with geographic distance, are significant predictors of trade potentials. Hence, gravity equations have been used extensively in the empirical literature on international trade (Havrylyshin and Pritchett, 1991; Frankel and Wei, 1993; Bayoumi and Eichengreen, 1997; Evenett and Hutchinson, 2002).

Filippini (2003) used a gravity Equation model to analyze trade flows between East Asian industrializing countries (including China) and some developed countries in order to show the remarkable trade performance of East Asian countries. The study showed that all coefficient signs were consistent with model assumptions and found high propensity of Asian countries (including China but excluding Japan) to exchange high-tech manufactured products with Japan and USA. Another interesting result was that among the East Asian economies, China plays a very important role as an exporter and as an importer too in recent years.

Martinez-Zarzoso (2003) applied the gravity model to annual bilateral exports between 19 countries. His results indicated that incomes of exporter and importer, as expected, had positive influence on bilateral trade flows. Population had a large and positive impact on import, indicating that bigger countries import more than do small countries. Regarding transport infrastructure, he found that exporting countries' infrastructure fosters trade. Achay. (2006) investigated the determinants of trade flows between various countries of the world. He applied the gravity model on a sample of 146 countries for five-year sub-periods between 1970 and 2000. According to this study, GDP, distance and regional integration agreements are the determinants of trade. It is also found that all estimated coefficients were statistically significant and their signs were in conformity with expectations. The adjustment quality of the model as measured by determination coefficient (adjusted $\mathrm{R}^{2}$ ) was quite high, standing at 71 percent. It was found that GDP, GDP per capita, common frontier, common official language, common currency or common colonial past have a positive impact on the volume of bilateral trade. On the other hand, the geographical distance had a negative impact on the volume of trade.

Very few studies on Bangladesh have been conducted so far in this area, which is perhaps due to unavailability of information, particularly regarding trade inflows and outflows with partner countries. Rahman (2004) applied a generalized gravity model to analyze Bangladesh trade flows with its trading partners using the panel data estimation techniques. The study estimated the gravity model of trade (sum of imports and exports). The results showed that Bangladesh's trade is positively determined by the size of the economies, per capita GNP (gross national product) differential of the countries involved and openness of the trading countries. The major determinants of Bangladesh's exports were found to be exchange rate, partner countries' total import demand, and openness of the economy. All these factors affected Bangladesh's exports positively whereas transportation cost was found to be a significant factor in influencing trade negatively.

From the extensive literature, gravity equations share common features that can be customized for different purposes: First, a gravity equation is bilateral; Secondly, gravity equations can be derived from various theoretical trade models 
(Deardorff, 1995) and finally, a gravity equation may be used in order to estimate either determinants of the volume or determinants of the nature of trade flows.

\section{Data and Model Specification}

Classical gravity models generally use cross-section data to estimate trade effects and trade relationships for a particular time, for example one year. In reality, however, eight cross-section data observed over several periods (panel data methodology) result in more useful information than does cross-section data alone. There is couple of advantages of this method. First, panels can capture the relevant relationships among variables over time. Second, panels can monitor unobservable trading-partner-pairs' individual effects. If individual effects are correlated with the regressors, OLS estimates omitting individual effects will be biased. Therefore, the paper used panel data methodology for testing empirical gravity.

This panel study covers yearly data for Bangladesh and its eight major partner countries from 1985 to 2003 ; a balance panel of total 684 observations. The countries - India, China, Singapore, Japan, Hong Kong, South Korea, United States of America (USA) and Malaysia- are chosen based on the share of total import volumes of Bangladesh. These eight countries cover most of the imports of Bangladesh (Table-3). Bangladesh imported 64 percent in 1996, 60 percent in 2001 and 2002 of its total import from these eight countries.

$<<$ Table $3>>$

Data for total import flows of Bangladesh (million US\$) have been taken from Economic Review of Bangladesh. Then it has been converted into real value by adjusting with the US consumer price index (constant year 2000). GDP data are also in real term (constant 2000 million US\$) that have been taken from World Development Indicators (WDI-2007) database. Population data (in million) were also taken from World Development Indicators (WDI-2007) database. Geographical distance in kilometers has been gathered from a web based database (www.timeanddate.com). All of these data have been converted into logarithmic ( $\ln$ ) format. For the statistical output, the SAS has been used and for the panel regression, the TSCSreg procedure has been used.

In 1687, Newton proposed the "Law of Universal Gravitation." It held that the attractive force between two objects $i$ and $j$ is given by,

$$
F i j=G\left(M i M j / D^{2} i j\right)
$$

Where notation is defined as follows, Fij is the attractive force, $M i$ and $M j$ are the masses, Dij is the distance between the two objects and $G$ is a gravitational constant depending on the units of measurement for mass and force.

This model originates from the Newtonian physics notion. Newton's Gravity Law in mechanics states that two bodies attract each other proportionally to the product of each body's mass (in kilograms) divided by the square of the distance between their respective centers of gravity (in meters). The gravity model has been applied to a wide variety of goods and factors of production moving across regional and national boundaries under different circumstances since the early $1940 \mathrm{~s}$ (Oguledo and Macphee, 1994).

The gravity model for trade is analogous to this law. The analogy is as follows: "the trade flow between two countries is proportional to the product of each country's 'economic mass', generally measured by GDP, each to the power of quantities to be determined, divided by the distance between the countries' respective 'economic centers of gravity', generally their capitals, raised to the power of another quantity to be determined" (Christie, 2002). This formulation can be generalized to,

$$
\mathrm{Mij}=\mathrm{K} \mathrm{Yi}^{\beta}{ }_{1} \mathrm{Yj}^{\beta}{ }_{2} \mathrm{Dij}^{\gamma} \operatorname{pop}_{\mathrm{i}}{ }^{\delta}{ }_{1} \mathrm{pop}_{\mathrm{j}}{ }_{2}
$$

The linear form of the model is as follows:

$$
\ln (\mathrm{Mij})=\mathrm{K}+\beta_{1} \ln (\mathrm{Yi})+\beta_{2} \ln (\mathrm{Yj})+\gamma \ln (\mathrm{Dij})+\delta_{1} \ln (\mathrm{POPi})+\delta_{2} \ln (\mathrm{POPj})
$$

The basic statistical model is specified in the following logarithmic form in which five variables are assumed to determine the import flows to Bangladesh from its major trading partners:

$$
\ln (\mathrm{Mij})=\alpha+\beta_{1} \ln (\mathrm{Yi})+\beta_{2} \ln (\mathrm{Yj})+\gamma \ln (\mathrm{Dij})+\delta_{1} \ln (\mathrm{POPi})+\delta_{2} \ln (\mathrm{POPj})+\mathrm{u}_{\mathrm{t}}
$$

where, Mij is the flow of Bangladesh's $(i)$ imports from partner country $(j), Y i$ is Bangladesh's GDP, $Y j$ is the partner countries' GDP, Dij is the geographical distance between Bangladesh's $(i)$ capital city to partner countries' $(j)$ capital city, $P O P i$ is Bangladesh's population, $P O P j$ is the partner countries' population, $u$ is the random error term and $\beta$, $\gamma, \delta$ are the structural parameters.

Here, this paper also observes the result for the basic model excluding the population variable from Equation no.-4, because there are few very highly populated countries such as China, India, and USA are available in partner countries' list that may impact the overall results. In this case the model is:

$$
\ln (\mathrm{Mij})=\alpha+\beta_{1} \ln (\mathrm{Yi})+\beta_{2} \ln (\mathrm{Yj})+\gamma \ln (\mathrm{Dij})+\mathrm{u}_{\mathrm{t}}
$$


The general hypothesis of the model is that the economic size of the importing countries, Mij, are usually measured with GDP. The estimated coefficients are usually close to the predicted value of one. If GDP of a country increases, the country is expected to import more from foreign countries. The same holds true for the partner countries that are exporters. So, both $\beta_{1}$ and $\beta_{2}$ are expected to be positive.

Distance is usually measured using the "great circle" formula. This formula approximates the shape of the earth as a sphere and calculates the minimum distance along the surface. As the distance between countries becomes larger, imports will fall. The distance is a factor, which is used as a proxy to consider the impact of transport costs and other transaction costs. Hummels, et al. (2007) have argued that shipping costs (freight charges and marine insurance) can go a long way towards explaining why distance matters. Distance indicates the time elapsed during shipment. For perishable goods, the probability of surviving intact is a decreasing function of time in transit. In gravity model, distance is a resistance factor and has a negative impact on volume of bilateral trade. As a result, $\gamma$ is expected to be negative.

The coefficient of population of the exporters may have negative or positive sign depending on whether the country exports less when it is big (absorption capacity) or whether a big country exports more compared to a small country (economies of scale). For similar reasons, the coefficient of importer population may have negative or positive sign (Martinez-Zarzoso and Nowak-Lehmann, 2003). Therefore, the expected signs of $\delta 1$ and $\delta_{1}$ may be negative or positive.

\section{Results of Analysis}

As the data has been taken from the countries of different regions and different economy sizes, here pooled OLS is not used. Moreover, geographical distance is fixed and not time sensitive. When working with constant data over time, time effect provides no output. Due to time constant, variable included in the equation-4 and equation-5, fixed effect model does not provide a good output. Moreover, $m$-value of Hausman test for equation-4 is insignificant, even in 90 percent confidence level which indicates to use fixed effect model. However, $m$-value of Hausman test for equation-5 is significant at 99 percent confidence level which indicates to use random effect model.

$<<$ Table $4>><<$ Table $5>><<$ Table $6>><<$ Table $7>><<$ Table $8>>$

$<<$ Table $9>><<$ Table $10>><<$ Table $11>><<$ Table $12>><<$ Table $13>>$

Domestic GDP has no significant impact on the imports of Bangladesh both in random effect and fixed effect model for the qeutions-4. However, the GDP of Bangladesh shows significant positive relationships with imports of Bangladesh both in random effect and one way fixed effect model for the qeutions-5. The coefficients of determination $\left(\mathrm{R}^{2}\right)$ of random effect models for both cases indicate that 80 percent of the total variation in the dependent variable is accounted for by the independent variables that indicate good fit of the model. However, a qualitative focus can give an in depth idea about the study. Imports criteria show that it influences the domestic production very little because Bangladesh mostly imports consumer goods rather than capital goods. One third of total imports of Bangladesh were capital goods in 2000, but in recent years the rate declines to 9 percent in 2004-05, 11 percent in 2005-06, and 12 percent in 2006-07 (Table-14). As a developing and trade deficit country it is alarming for Bangladesh that the rate of total imports is increasing but the ratio of capital goods is decreasing.

$<<$ Table 14>>

Due to time irresponsible fixed value, the fixed effect models do not provide any output for geographical distance variable. The random effect models show significant negative impacts of geographical distance on the imports of Bangladesh, which is accepted at the 99 percent confidence level for both equation- 4 and equation-5. It is noted that here the sign of the coefficient is negative, means less geographical distance influence for higher import and vice versa. This result supports the theory of gravity model. However, recently Bangladesh has started to move its trade from lower distance country to higher distance country. The model of gravity mainly considers the geographical distance for trade, but the reality is more complex that might cause the inconsistency of this result in near future. There are lots of factors available that go beyond the assumption of gravity theory, such as, Bangladeshi importers are interested in China because it is offering goods with a wide price range, easy trade procedures, many duty free goods, shorter timing of shipment etc. China usually sends its products to Bangladesh within 25 days on an average by completing all the formalities while import from India takes 35 days. Many Chinese products, such as, food stuff, plastic goods, rubber goods, wooden products, raw hides, pulp, papers, electrical machinery and equipment and parts thereof, sound recorders and reproducers, television accessories of electronics articles, boilers, machinery and mechanical appliances, parts thereof, Cotton, yarn/thread and cotton fabrics etc., are cheap compared to the same quality products of India.

Both random effect and one-way fixed effect models show that domestic population has significant positive impacts on the imports of Bangladesh (equation-4). At 96 percent confidence level, one-way fixed effect model shows that 1 percent increases in domestic population will lead to 5.65 percent increases in imports of Bangladesh. And at 99 percent confidence level random effect models show that 1 percent increases in domestic population will lead to 7.19 percent increases in imports of Bangladesh. That means Bangladesh is not capable to produce enough in proportion of increasing 
demand due to population growth. As a result, demand for import increases five to eight times of the rate of its population increases.

Partner countries' GDP has significant positive impacts on the imports of Bangladesh both for equation-4 and equation-5. If Bangladesh imports more, the partner countries will produce more to meet the demand of Bangladesh. Fixed effect model shows no impact of Partner countries' population on Bangladeshi imports, where random effect models show significant negative impact.

\section{Conclusion}

Recently trade of Bangladesh is decreasing with its border countries and trade volume is increasing with far distance countries, such as, the case of China and India. Therefore, to find out the impacts of gravity model on the trade patterns of Bangladesh, its import is tested on home GDP, partner countries' GDP, geographical distance between home capital city and partner countries' capital city, home population, and partner countries' population.

The paper finds mixed results for the impact of Bangladeshi GDP on its imports. If population is not considered, GDP shows positive relationships with imports of Bangladesh. In a quantities focus, imports criteria show that it influences the domestic production very little because Bangladesh mostly imports consumer goods rather than capital goods. Further, population of home country has highly significant impact on imports of Bangladesh. It in turn implies that Bangladesh is not capable of producing enough in proportion of increasing demand due to population growth. Partner countries' GDP has significant positive impacts on the imports of Bangladesh and partner countries' population has mixed results on imports of Bangladesh.

Most importantly it is found that geographical distance has significant impact on imports of Bangladesh which means transport costs and other transaction costs, such as, the probability of surviving intact of perishable goods etc. still have significant impacts on its import. But in recent phenomenon, the imports are more influenced by profitability, easy trade procedures, product delivery time etc., rather than the geographical distance. As a consequence, policy makers need to conduct further serious studies to find out the relationship, if any, between trading pattern, geographical distance and trade deficits of Bangladesh. Policy makers also need to carefully consider the future alarming situation for trade balance of Bangladesh if the import increases continuously in such a pattern that the rate increases five to eight times more in respect of population increases and at the same time the ratio of capital goods in proportion of total imports decreases.

\section{References}

Achay, L. (2006). Assessing Regional Integration in North Africa. National Institute of Statistics and Applied economics, Rabat, Morocco.

Anderson, J. E. and Wincoop, E.v. (2003). Gravity with Gravitas: A Solution to the Border Puzzle. American Economic Review, 93(1), 170-192.

Bayoumi, T. and Eichengreen, B. J. (1997). Is regionalism Simply a Diversion? Evidence from the Evolution of the EC and EFTA. Takatoshi Ito and Anne O Krueger (eds.), Regionalism vs. Multilateral Arrangements. Chicago: The University of Chicago Press.

Bangladesh Bank (2004-2005, 2005-2006). Import Payments (annual). Department of Public Relations \& Publication, Dhaka, Bangladesh.

Bergstrand, J. H. (1989). The Generalized Gravity Equation, Monopolistic Competition, and the Factor-Proportions Theory of International Trade. Review of Economics and Statistics, 71, 143-153.

Christie, E. (2002). Potential Trade in Southeast Europe: A Gravity Model Approach. Working Paper No. 21. The Vienna Institute for International Economic Studies-WIIW.

Deardorff, A. V. (1995). Determinants of Bilateral Trade: Does Gravity Work in a Neoclassical World?. Working Paper No. W5377. National Bureau of Economic Research (NBER).

Evenett, S. J. and Hutchinson,W. K. (2002). The Gravity Equation in International Economics: Theory and Evidence. Scottish Journal of Political Economy, 49(5), 489-490.

Filippini, C. and Molini, V. (October 2003). The Determinants of East Asian Trade Flows: A Gravity Equation Approach. Journal of Asian Economics, 14(5), 695-711(17).

Frankel, J. A. and Wei, S. j. (1993). Trade Blocs and Currency Blocs. Working Paper No. W4335. National Bureau of Economic Research (NBER).

Havrylyshyn, O. and Pritchett, L. (1991). European Trade Patterns after the Transitions. Policy Research Working Paper Series 748. World Bank.

Hill, L. W. C. (2004). Global Business Today (pp. 5). New York: McGraw Hill Irwin. 
Hummels, D., Volodymyr, L., and Skiba, A. (2007). The Trade Reducing Effects of Market Power in International Shipping. Working paper no. W12914. National Bureau of Economic Research (NBER).

Linnemann, H. (1966). An Economic Study of International Trade Flows. Amsterdam: North-Holland.

Martínez-Zarzoso, I., and Nowak-Lehmann, F. D. (2003). Augmented Gravity Model: An empirical application to Mercosur-European Union trade flows. Journal of Applied Economics, 6(2), 291-316.

Oguledo, V. I. and Macphee, C. R. (1994). Gravity Models: A Reformulation and an Application to Discriminatory Trade Arrangements. Applied Economics, 26(2), 107-120.

Rahman, M. (2004). The Determinants of Bangladesh's Trade: Evidence from the Generalised Gravity Model. The Economic Society of Australia's 33 Conference of Economists, University of Sydney, Australia.

Razzaque, A. and Raihan, S. (2007). WTO and Regional Trade Negotiation Outcomes: Quantitative Assessments of Potential Implications on Bangladesh. Pathak Shamabesh, 150-152.

Tinbergen, J. (1962). Shaping the World Economy: Suggestions for an International Economic Policy. New York: The Twentieth Century Fund.

www.timeanddate.com

Table 1. Trade Balance of Bangladesh (Million US \$)

\begin{tabular}{|c|c|c|c|}
\hline Year & Goods Imports & Goods Exports & Trade Balance \\
\hline $\mathbf{1 9 8 5}$ & 2,286 & 999 & $-1,287$ \\
\hline $\mathbf{1 9 8 6}$ & 2,301 & 880 & $-1,421$ \\
\hline $\mathbf{1 9 8 7}$ & 2,446 & 1,077 & $-1,369$ \\
\hline $\mathbf{1 9 8 8}$ & 2,734 & 1,291 & $-1,443$ \\
\hline $\mathbf{1 9 8 9}$ & 3,300 & 1,305 & $-1,995$ \\
\hline $\mathbf{1 9 9 0}$ & 3,259 & 1,672 & $-1,587$ \\
\hline $\mathbf{1 9 9 1}$ & 3,074 & 1,689 & $-1,386$ \\
\hline $\mathbf{1 9 9 2}$ & 3,354 & 2,098 & $-1,256$ \\
\hline $\mathbf{1 9 9 3}$ & 3,657 & 2,545 & $-1,113$ \\
\hline $\mathbf{1 9 9 4}$ & 4,351 & 2,934 & $-1,416$ \\
\hline $\mathbf{1 9 9 5}$ & 6,057 & 3,733 & $-2,324$ \\
\hline $\mathbf{1 9 9 6}$ & 6,285 & 4,009 & $-2,275$ \\
\hline $\mathbf{1 9 9 7}$ & 6,551 & 4,840 & $-1,711$ \\
\hline $\mathbf{1 9 9 8}$ & 6,716 & 5,141 & $-1,574$ \\
\hline $\mathbf{1 9 9 9}$ & 7,536 & 5,458 & $-2,077$ \\
\hline $\mathbf{2 0 0 0}$ & 8,053 & 6,399 & $-1,654$ \\
\hline $\mathbf{2 0 0 1}$ & 8,133 & 6,085 & $-2,049$ \\
\hline $\mathbf{2 0 0 2}$ & 7,780 & 6,102 & $-1,678$ \\
\hline $\mathbf{2 0 0 3}$ & 9,492 & 7,050 & $-2,442$ \\
\hline $\mathbf{2 0 0 4}$ & 11,157 & 8,151 & $-3,006$ \\
\hline $\mathbf{2 0 0 5}$ & 12,292 & 9,186 & $-3,105$ \\
\hline
\end{tabular}

Source: World Development Indicators, 2007 
Table 2. Common Commodity Imports by Bangladesh from China and India

\begin{tabular}{|l|c|c|c|c|}
\hline \multicolumn{1}{|c|}{ Group-wise Commodity } & \multicolumn{2}{c|}{ China (TK in Millions) } & \multicolumn{2}{c|}{ India (TK in Millions) } \\
\cline { 2 - 5 } & $2005-2006$ & $2004-2005$ & $2005-2006$ & $2004-2005$ \\
\hline Cotton,(all types) cotton yarn/thread and cotton fabrics & 2,987 & 2,072 & 2,284 & 1,246 \\
\hline Boilers, Machinery and mechanical appliances, parts thereof & 2,094 & 1,595 & 994 & 1,147 \\
\hline $\begin{array}{l}\text { Electrical machinery and equipment and parts thereof, sound } \\
\text { recorders and reproducers, television image and sound } \\
\text { recorders and reproducers and parts and accessories of such } \\
\text { articles }\end{array}$ & & & & \\
\hline Man-made staple fibers & 1,334 & 636 & 323 & 302 \\
\hline Knitted or crocheted fabrics & 1,016 & 884 & 286 & 267 \\
\hline $\begin{array}{l}\text { Vehicles other than railway or tramway, rolling stock and parts } \\
\text { and accessories thereof }\end{array}$ & 857 & 665 & 91 & 93 \\
\hline Plastics and articles thereof & 214 & 200 & 704 & 504 \\
\hline Cereals & 164 & 98 & 474 & 444 \\
\hline
\end{tabular}

Source: Bangladesh Bank (2004-2005, 2005-2006), Import Payments (annual), Department of Public Relations \&

Publication, Dhaka, Bangladesh.

Table 3. Goods Import Market Shares of the Eight Major Trading Partners of Bangladesh

\begin{tabular}{|c|c|c|c|c|c|c|c|c|c|c|c|}
\hline Year & India & China & Singapore & Japan & Hong-Kong & $\begin{array}{c}\text { S. } \\
\text { Korea }\end{array}$ & USA & Malaysia & $\begin{array}{c}\text { Sub-Total } \\
\text { (a) }\end{array}$ & $\begin{array}{l}\text { Total } \\
\text { Imports } \\
\text { (b) }\end{array}$ & $\begin{array}{c}\text { (a) } \\
\text { as \% } \\
\text { of (b) }\end{array}$ \\
\hline 1985 & 67 & 90 & 291 & 301 & 51 & 56 & 286 & 48 & 1,190 & 2,286 & $52.1 \%$ \\
\hline 1986 & 60 & 74 & 209 & 255 & 46 & 64 & 164 & 27 & 899 & 2,301 & $39.1 \%$ \\
\hline 1987 & 64 & 82 & 156 & 378 & 68 & 64 & 178 & 24 & 1,014 & 2,446 & $41.5 \%$ \\
\hline 1988 & 87 & 91 & 145 & 456 & 112 & 82 & 216 & 36 & 1,225 & 2,734 & $44.8 \%$ \\
\hline 1989 & 104 & 110 & 186 & 445 & 116 & 103 & 325 & 50 & 1,439 & 3,300 & $43.6 \%$ \\
\hline 1990 & 145 & 132 & 323 & 475 & 157 & 126 & 208 & 41 & 1,607 & 3,259 & $49.3 \%$ \\
\hline 1991 & 181 & 133 & 334 & 336 & 184 & 165 & 181 & 32 & 1,546 & 3,074 & $50.3 \%$ \\
\hline 1992 & 231 & 149 & 275 & 286 & 247 & 181 & 230 & 42 & 1,641 & 3,354 & $48.9 \%$ \\
\hline 1993 & 342 & 248 & 211 & 365 & 299 & 258 & 207 & 53 & 1,983 & 3,657 & $54.2 \%$ \\
\hline 1994 & 414 & 223 & 200 & 498 & 331 & 284 & 202 & 57 & 2,209 & 4,351 & $50.8 \%$ \\
\hline 1995 & 689 & 420 & 275 & 587 & 399 & 340 & 274 & 41 & 3,025 & 6,057 & $49.9 \%$ \\
\hline 1996 & 1,100 & 707 & 343 & 695 & 390 & 366 & 330 & 69 & 4,000 & 6,285 & $63.6 \%$ \\
\hline 1997 & 922 & 575 & 297 & 647 & 409 & 360 & 302 & 197 & 3,709 & 6,551 & $56.6 \%$ \\
\hline 1998 & 934 & 593 & 321 & 483 & 443 & 381 & 311 & 172 & 3,638 & 6,716 & $54.2 \%$ \\
\hline 1999 & 1,235 & 560 & 553 & 494 & 452 & 287 & 301 & 131 & 4,013 & 7,536 & $53.3 \%$ \\
\hline 2000 & 833 & 568 & 701 & 685 & 455 & 319 & 325 & 108 & 3,994 & 8,053 & $49.6 \%$ \\
\hline 2001 & 1,184 & 709 & 824 & 846 & 478 & 411 & 248 & 148 & 4,848 & 8,133 & $59.6 \%$ \\
\hline 2002 & 1,019 & 878 & 871 & 655 & 441 & 346 & 261 & 145 & 4,616 & 7,780 & $59.3 \%$ \\
\hline 2003 & 1,358 & 938 & 1,000 & 605 & 433 & 333 & 223 & 169 & 5,059 & 9,492 & $53.3 \%$ \\
\hline
\end{tabular}

Source: Bangladesh Economic Review, Ministry of Finance, 2005 
Table 4. Model Efficiency Random Effect (Eq No. 4)

\begin{tabular}{lllll}
\hline Method & m-Value & m-Prob. & d o f & $\mathrm{R}^{2}$ \\
\hline One-way Random Effect & 5.33 & 0.15 & 3 & 0.82 \\
Two-way Random Effect & 4.16 & 0.13 & 2 & 0.81 \\
\hline
\end{tabular}

Table 5. Model Efficiency for Random Effect (Eq No. 5)

\begin{tabular}{lllll}
\hline Method & m-Value & m-Prob. & d o f & $\mathrm{R}^{2}$ \\
\hline One-way Random Effect & $21.01 *$ & 0.000 & 2 & 0.79 \\
Two-way Random Effect & $8.11 *$ & 0.004 & 1 & 0.79 \\
\hline
\end{tabular}

* Significant at $99 \%$ confidence level

Table 6. Model Efficiency for Fixed Effect (Eq No. 4)

\begin{tabular}{llllll}
\hline \multirow{2}{*}{ Method } & & & \multicolumn{2}{l}{ Numerator } & \multicolumn{2}{l}{ Denominator } \\
& F-Value & F-Prob. & d o f & d o f & $\mathrm{R}^{2}$ \\
\hline One-way Fixed Effect & $40.1 *$ & 0.000 & 7 & 139 & 0.88 \\
Two-way Fixed Effect & $31.96 *$ & 0.000 & 25 & 121 & 0.89 \\
\hline
\end{tabular}

* Significant at $99 \%$ confidence level

Table 7. Model Efficiency for Fixed Effect (Eq No. 5)

\begin{tabular}{|c|c|c|c|c|c|}
\hline Method & F-Value & F-Prob. & $\begin{array}{l}\text { Numerator } \\
\text { d o f }\end{array}$ & $\begin{array}{l}\text { Denominator } \\
\text { d o f }\end{array}$ & $\mathrm{R}^{2}$ \\
\hline One-way Fixed Effect & $41.4 *$ & 0.000 & 7 & 141 & 0.87 \\
\hline Two-way Fixed Effect & $32.33 *$ & 0.000 & 25 & 123 & 0.89 \\
\hline
\end{tabular}

* Significant at $99 \%$ confidence level

Table 8. Both One-way and Two-way Random Effect Regression Output (Eq No. 4) (Dependent Variable: ln (Mij)

\begin{tabular}{llll}
\hline Model & Coefficient & t-Value & p-Value \\
\hline Constant & $-7.67^{* *}$ & -1.85 & 0.07 \\
$\ln (\mathrm{Yi})$ & -1.59 & -1.31 & 0.19 \\
$\ln (\mathrm{Yj})$ & $1.07^{*}$ & 5.52 & 0.0001 \\
$\ln (\mathrm{Dij})$ & $-2.03^{*}$ & -4.13 & 0.0001 \\
$\ln (\mathrm{POPi})$ & $7.19 *$ & 2.76 & 0.007 \\
$\ln (\mathrm{POPj})$ & $-0.41 *$ & -3.12 & 0.002 \\
\hline
\end{tabular}

* Significant at $99 \%$ confidence level, $* *$ Significant at $90 \%$ confidence level

Table 9. One-way Fixed Effect Regression Output (Eq No. 4)(Dependent Variable: ln (Mij)

\begin{tabular}{llll}
\hline Model & Coefficient & t-Value & p-Value \\
\hline Constant & $-28.31^{*}$ & -12.8 & 0.0001 \\
$\ln (\mathrm{Yi})$ & -1.29 & -1.08 & 0.28 \\
$\ln (\mathrm{Yj})$ & $1.43^{*}$ & 5.28 & 0.0001 \\
$\ln (\mathrm{Dij})$ & 0 & - & - \\
$\ln (\mathrm{POPi})$ & $5.65^{*}$ & 2.12 & 0.04 \\
$\ln (\mathrm{POPj})$ & -0.39 & -0.48 & 0.63 \\
\hline
\end{tabular}

* Significant at $95 \%$ confidence level 
Table 10. Two-way Fixed Effect Regression Output (Eq No. 4)(Dependent Variable: ln (Mij)

\begin{tabular}{llll}
\hline Model & Coefficient & t-Value & p-Value \\
\hline Constant & $-13.68^{*}$ & -2.90 & 0.004 \\
$\ln (\mathrm{Yi})$ & 0 & - & - \\
$\ln (\mathrm{Yj})$ & $1.41 *$ & 5.15 & 0.0001 \\
$\ln (\mathrm{Dij})$ & 0 & - & - \\
$\ln (\mathrm{POPi})$ & 0 & - & - \\
$\ln (\mathrm{POPj})$ & -0.54 & -0.66 & 0.51 \\
\hline
\end{tabular}

* Significant at $99 \%$ confidence level

Table 11. Both One-way and Two-way Random Effect Regression Output (Eq No. 5) (Dependent Variable: In (Mij))

\begin{tabular}{clll}
\hline Model & Coefficient & t-Value & p-Value \\
\hline Constant & $-13.67 *$ & -3.39 & 0.0009 \\
$\ln (\mathrm{Yi})$ & $2.06 *$ & 9.27 & 0.0001 \\
$\ln (\mathrm{Yj})$ & $0.78^{*}$ & 5.33 & 0.0001 \\
$\ln (\mathrm{Dij})$ & $-1.57^{*}$ & -3.35 & 0.001 \\
\hline
\end{tabular}

* Significant at $99 \%$ confidence level

Table 12. One-way Fixed Effect Regression Output (Eq No. 5) (Dependent Variable: In (Mij))

\begin{tabular}{llll}
\hline Model & Coefficient & t-Value & p-Value \\
\hline Constant & $-31.06^{*}$ & -21.07 & 0.0001 \\
$\ln (\mathrm{Yi})$ & $1.11 *$ & 3.73 & 0.003 \\
$\ln (\mathrm{Yj})$ & $1.56^{*}$ & 7.00 & 0.0001 \\
$\ln (\mathrm{Dij})$ & 0 & - & - \\
\hline
\end{tabular}

* Significant at $99 \%$ confidence level

Table 13. Two-way Fixed Effect Regression Output (Eq No. 5) (Dependent Variable: ln (Mij))

\begin{tabular}{llll}
\hline Model & Coefficient & t-Value & p-Value \\
\hline Constant & $-15.39^{*}$ & -3.89 & 0.0002 \\
$\ln (\mathrm{Yi})$ & 0 & - & - \\
$\ln (\mathrm{Yj})$ & $1.33^{*}$ & 5.49 & 0.0001 \\
$\ln (\mathrm{Dij})$ & 0 & - & - \\
\hline
\end{tabular}

* Significant at $99 \%$ confidence level 
Table 14. Category-Wise Yearly Imports of Bangladesh (Million US \$)

\begin{tabular}{|c|c|c|c|c|c|c|}
\hline Major Commodities & 2001-02 & $2002-03$ & 2003-04 & 2004-05 & 2005-06 & 2006-07 \\
\hline FOOD GRAINS & 186 & 409 & 431 & 574 & 418 & 581 \\
\hline Milk \& cream & 59 & 61 & 61 & 86 & 73 & 83 \\
\hline Oil seeds & 72 & 64 & 73 & 86 & 90 & 106 \\
\hline Edible oil & 251 & 364 & 471 & 441 & 473 & 583 \\
\hline Pulses all sorts & 88 & 145 & 120 & 159 & 164 & 195 \\
\hline Sugar & 23 & 104 & 110 & 220 & 124 & 294 \\
\hline Clinker & 150 & 144 & 139 & 170 & 210 & 240 \\
\hline Crude petroleum & 242 & 267 & 252 & 350 & 604 & 524 \\
\hline POL & 481 & 620 & 770 & 1252 & 1400 & 1709 \\
\hline Chemical & 335 & 353 & 406 & 510 & 580 & 668 \\
\hline Pharmaceutical products & 39 & 44 & 45 & 41 & 50 & 49 \\
\hline Fertilizer & 107 & 109 & 150 & 332 & 342 & 357 \\
\hline Dyeing, tanning etc. materials & 87 & 86 & 109 & 132 & 148 & 161 \\
\hline Plastics and rubber articles thereof & 250 & 281 & 367 & 477 & 523 & 643 \\
\hline Raw cotton & 312 & 393 & 583 & 666 & 742 & 858 \\
\hline Yarn & 283 & 270 & 323 & 393 & 501 & 582 \\
\hline Textile and articles thereof & 1063 & 1106 & 1295 & 1571 & 1728 & 1892 \\
\hline Staple fiber & 39 & 41 & 57 & 75 & 76 & 97 \\
\hline Iron, steel and other base metals & 413 & 455 & 479 & 680 & 980 & 985 \\
\hline Capital goods & 2617 & 2735 & 2875 & 1115 & 1539 & 1929 \\
\hline Others & 803 & 848 & 870 & 2823 & 2887 & 3401 \\
\hline Subtotal : & 7913 & 8931 & 10016 & 12195 & 13684 & 16013 \\
\hline Imports of EPZ & 627 & 727 & 887 & 952 & 1062 & 1144 \\
\hline Grand Total : & 8540 & 9658 & 10903 & 13147 & 14746 & 17157 \\
\hline Capital Goods as \% of Total Import (Except EPZ) & $33 \%$ & $31 \%$ & $29 \%$ & $9 \%$ & $11 \%$ & $12 \%$ \\
\hline
\end{tabular}

Source: Bangladesh Bank, Import Payments Data, Available at

<http://www.bangladesh-bank.org/econdata/import/categoryimp.html> 